\title{
溶接継手の多段多重振幅における累積疲労損傷に関する研究 EXPERIMENTAL STUDY ON CUMULATIVE FATIGUE DAMAGE OF WELDED JOINTS UNDER MULTI STEP BLOCK AMPLITUDE
}

\author{
中込忠男*, 瀬戸洋平** \\ Tadao NAKAGOMI and Yohei SETO
}

\begin{abstract}
The safety of steel construction building cannot ignore effect of wind load because of an increase in high-rise building. Therefore, fatigue damage by wind load is important issue for steel frame. Currently, Miner's law is used generally for estimation method of fatigue life when stress amplitude varies as actual load. However, the recent studies report that the estimation of fatigue life by using Miner's law tends to exaggerate fatigue life. Therefore, we investigated the effects of the difference of the number of the steps, the damage proportion and the turn to give about amplitude on fatigue life by carrying out fatigue test. According to these effects, we proposed estimation method of fatigue life.
\end{abstract}

Keywords: Miner's law, Steel tubular joint, Fatigue life, Repeated multi step block amplitude マイナー則, 鋼管分岐継手, 疲労寿命, 多段多重繰返し振幅

1. はじめに

現在、日本の建築鉄骨において建物の高層化が進み、地震力だけ でなく風外力に対しての安全性確保も重要となっている。風外力に 対する疲労損傷の問題は、骨組の挙動が再現期間の長い強風時に弾 性範囲のみならず、弾性限近傍から塑性域にわたる範囲に及ぶこと が問題視されてきた ${ }^{1 \sim 4)}$ 。また、溶接接合部やダンパーでは中型地震 や大きな台風により局部的に塑性変形した状況下で、台風や季節風 などの低応力の数多くの繰返しにより通常よりも早く亀裂が発生し、 疲労破壊や大地震により脆性破壊を招く恐れがあり、疲労損傷に関 寸る安全性の検討が必要である。

これまでに建築鉄骨における疲労の研究は、風外力や小規模地震 を対象とした高サイクル疲労範囲（破断回数が $10^{4}$ 回以上）につい ての研究 5 ), 6 、地震も対象とした低サイクル疲労範囲 (破断回数が $10^{4}$ 回以下）についての研究7) 12)など多く行われてきた。しかし、今後 の大規模建築物の耐風安全性を考える上では、建築鉄骨において局 部的に塑性変形を起こすような弾塑性挙動の応力に関しての疲労損 傷の研究が重要となっている。

現在、疲労寿命を推定する方法としては、線形累積疲労損傷則 (以 下、マイナ一則 ${ }^{13)}$ とする。）と呼ばれる経験則が一般的に用いられて いるが、その法則の適用は過大評価となる危険性があると数多く言 われてきた ${ }^{14)}$ 。筆者ら ${ }^{15}$ ) は、SM490 鋼の素材試験で 2 段多重歪振幅
疲労実験を行い、累積疲労損傷度D (4.1 線形累積疲労損傷則に示 す。）が最小で 0.1 程度となりマイナー則の適用が過大評価となる危 険性を確認した。また、 $\Delta \mathrm{N}$ (4.2 2 段多重振幅疲労実験に示寸破 断回数の対数差。）を導入し疲労寿命の予測方法としてD值 - $\Delta \mathrm{N}$ 曲 線を示した。さらに、柱梁溶接接合部の 2 段多重振幅載荷実験 ${ }^{16)}$ で は、骨組試験体に対してもマイナー則の適用は過大評価となること を確認し、D值 - $\triangle \mathrm{N}$ 関係を示した。このようにマイナー則による応 力振幅変動下の疲労寿命の推定は過大評価となる危険性があり、累 積疲労損傷度に関する提案が必要である。また、マイナー則は一般 的に疲労限度以上の応力振幅について適用されるが、今後の弾塑性 域の疲労に関しては適用範囲を拡張して検討寸る必要がある。

本研究では、応力が集中しやすい溶接接合部の疲労強度および疲 労損傷を把握するため、トラスをモデル化したT字型鋼管分岐溶接 継手を用いて一定振幅疲労実験を行った。さらに、風荷重から中型 地震までの弾性及び弾塑性範囲の応力振幅を対象に 2 段から 4 段ま での多段多重振幅疲労実験を行い、筆者ら ${ }^{15}$ が示した $\mathrm{D}$ 值 - $\Delta \mathrm{N}$ 曲線 の関係を検討するとともに、その関係を発展した疲労寿命の推定法 を提案することを目的としている。また、一般的に溶接継手の止端 部には、引張の溶接残留応力が存在すると言われているが、本研究 では残留応力の影響は全ての試験体においてほぼ同じものとして扱 っている。
* 信州大学工学部建築学科 教授. 工博

** 信州大学大学院工学系研究科 大学院生
Prof., Dept. of Architecture, Faculty of Engineering, Shinshu Univ., Dr. Eng. Graduate Student, Faculty of Engineering, Shinshu Univ. 
表 1 使用鋼材の機械的性質

\begin{tabular}{c|c|c|c|c|c|c}
\hline 部位 & 鋼種 & $\begin{array}{c}\text { 外形 } \\
(\mathrm{mm})\end{array}$ & $\begin{array}{c}\text { 管厚 } \\
(\mathrm{mm})\end{array}$ & $\begin{array}{c}\text { 降伏点 } \\
\left(\mathrm{N} / \mathrm{mm}^{2}\right)\end{array}$ & $\begin{array}{c}\text { 引張強さ } \\
\left(\mathrm{N} / \mathrm{mm}^{2}\right)\end{array}$ & $\begin{array}{c}\text { 伸び } \\
(\%)\end{array}$ \\
\hline \hline 主管 & STK400 & 165.2 & 7.1 & 349 & 418 & 40.4 \\
\hline 支管 & STK400-E-G & 89.1 & 4.2 & 379 & 419 & 31.6 \\
\hline
\end{tabular}

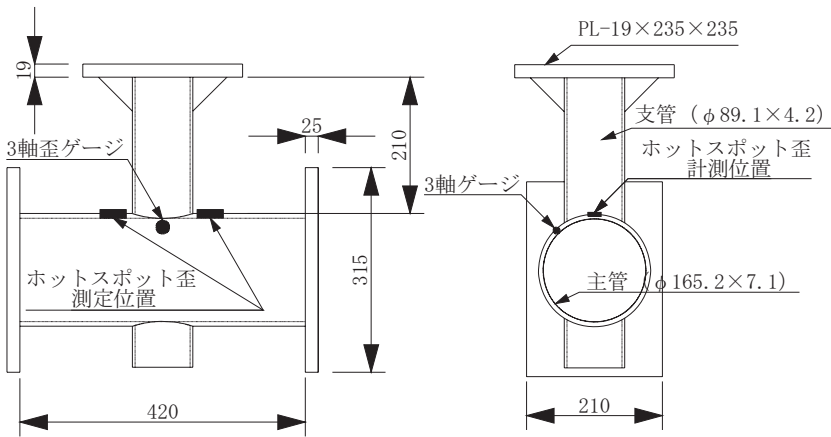

図 1 試験体形状・寸法及び 3 軸歪ゲージの貼付位置

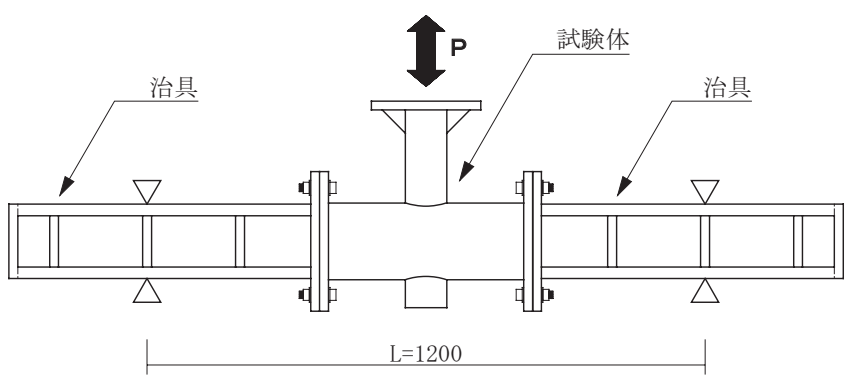

図 2 試験体加力図

\section{2. 実験概要}

\section{1 試験体}

試験体の鋼種は、一般構造用炭素鋼管で、主管が STK400（JIS G 3444）、支管が STK400-E-G（JIS G 3444）であり、表 1 に使用鋼材 の機械的性質を示す。また、試験体形状・寸法及び 3 軸歪ゲージの 貼付位置を図 1 に示寸。試験体寸法は、主管が外形 $165.2 \mathrm{~mm}$ 、管厚 $7.1 \mathrm{~mm}$ 、支管が外形 $89.1 \mathrm{~mm}$ 、管厚 $4.2 \mathrm{~mm}$ とした。

試験体は、パイプ自動プラズマ切断システムによる全自動切断で 行い、継手部の支管側にレ形開先を設け、 $\mathrm{CO}_{2}$ ガスシールドアーク 溶接により、入熱約 $6.9 \mathrm{~kJ} / \mathrm{cm}$ で突合せ溶接した。また、試験体の加 力点及び治具との接合部、加力点の補強用リブプレートに鋼板をす

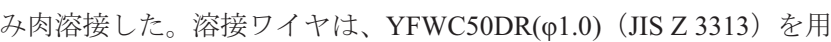
いた。

\section{2 実験方法}

載荷は、油圧式疲労試駼機を用いて、変位制御による完全両振り とし、常温で行った。図 2 に試験体加力図を示す。支点は両端回転 自由のピン支点とし、支点間距離は $1200 \mathrm{~mm}$ とした。治具及び加力 点との接合には高力ボルトを用いた。

図 3 にゲージ貼付位置詳細及びホットスポット応力の定義を示す。 3 軸歪ゲージは溶接止端部にできる限り近い位置で測定するため、 ゲージベースを考慮して溶接止端部からゲージ中心までの距離 $4 \mathrm{~mm}$ の位置とした。また、同図のように $\mathrm{x}$ 軸を水平方向、 $\mathrm{y}$ 軸を垂 直方向、その両軸に対して 45 度を $\mathrm{z}$ 軸方向として貼付した。

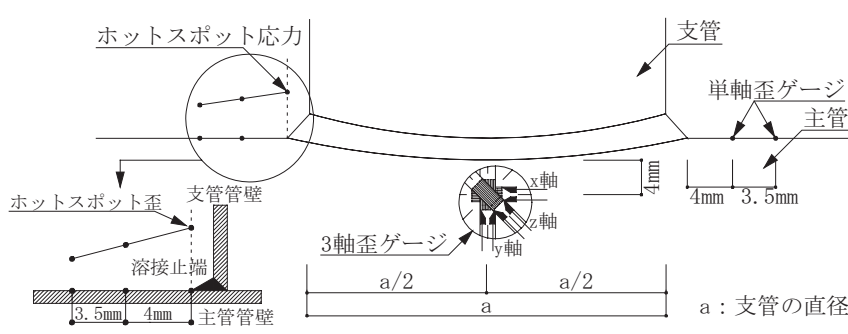

図 3 ゲージ貼付位置詳細及びホットスポット応力の定義

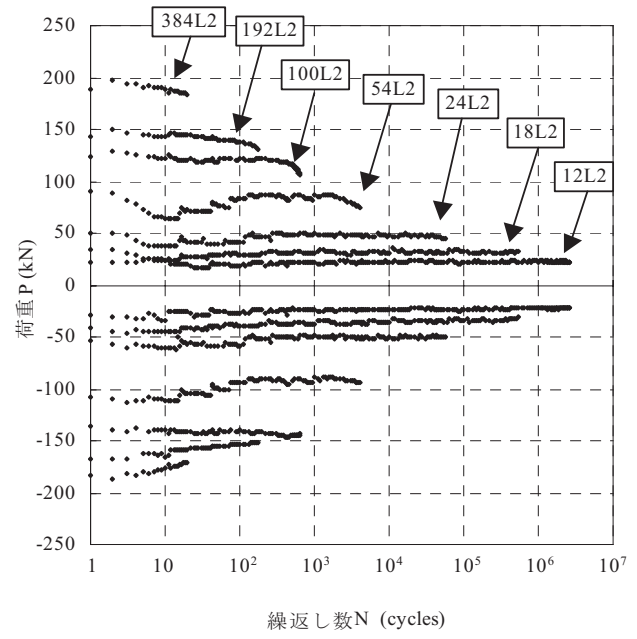

図 4 荷重履歴

3 軸歪ゲージの主歪 $(\mathrm{p} \varepsilon)$ は式(1)より算出し、載荷変位は全ての 実験においてこの主歪を用いて決定した。一定振幅疲労実験では載 荷開始からの数サイクルで変位を決定し、多段多重振幅疲労実験で は一定振幅の $\varepsilon-\mathrm{N}$ 線図の主歪から載荷変位を決定した。

$$
{ }_{p} \varepsilon=\frac{1}{2}\left[\varepsilon_{x}+\varepsilon_{y}+\sqrt{2\left\{\left(\varepsilon_{x}-\varepsilon_{z}\right)^{2}+\left(\varepsilon_{y}-\varepsilon_{z}\right)^{2}\right\}}\right]
$$

ここで、 $\varepsilon_{\mathrm{x}}$ はx 軸方向歪を、 $\varepsilon_{\mathrm{y}}$ はy軸方向歪を、 $\varepsilon_{\mathrm{z}}$ はz軸方向歪を表 す。主歪範囲 $(\triangle \mathrm{p} \varepsilon)$ は主歪の引張側と圧縮側の差である。

また、図 3 に示寸ようにホットスポット応力を求めるため、溶接 止端部から $4 \mathrm{~mm}$ と $7.5 \mathrm{~mm}$ の 2 点を直線で結び外挿上の溶接止端位置 の応力を単軸歪ゲージより求めた。止端のホットスポット忘力に対 寸る歪 $\left(\Delta \varepsilon_{\mathrm{t}}\right)$ は、同図の 2 箇所の歪がほぼ同じ值となったため 2 箇所の平均值とした。

載荷波形は実験中に一定の歪速度を保つために三角波を用い、歪 速度は、 $10^{-2} / \mathrm{sec}$ 以上では塑性域において疲労寿命に与える影響が大

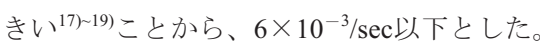

耐力低下回数は、荷重範囲（ $\triangle \mathrm{P} ）$ が安定したときを基準とし、 その基準值から荷重範囲が $95 \%$ まで低下したときの繰返し数とした。 また、亀裂の確認は、マイクロスコープ及び目視で行った。

\section{3. 一定振幅疲労実験}

実験は、主歪範囲が $0.073 \sim 1.500 \%$ で 7 体について行った。ここ で、耐力低下回数を疲労寿命 $\left(\mathrm{N}_{\mathrm{f}}\right)$ と称す。また、荷重履歴を図 4 に示す。

載荷応力が弾性域と塑性域にまたがる振幅下であり、各応力レベ 
表 2 一定振幅疲労実験結果

\begin{tabular}{|c|c|c|c|c|c|c|}
\hline 試験体名 & $\begin{array}{c}\Delta_{\mathrm{p}} \varepsilon \\
(\%) \\
\end{array}$ & $\begin{array}{c}\triangle{ }_{\mathrm{p}} \varepsilon_{\mathrm{e}} \\
(\%)\end{array}$ & $\begin{array}{c}\triangle_{\mathrm{p}} \varepsilon_{\mathrm{p}} \\
(\%) \\
\end{array}$ & $\begin{array}{c}\Delta \varepsilon_{\mathrm{t}} \\
(\%) \\
\end{array}$ & $\begin{array}{c}\mathrm{N}_{\mathrm{c}} \\
\text { (cycles) } \\
\end{array}$ & $\begin{array}{c}\mathrm{N}_{\mathrm{f}} \\
\text { (cycles) } \\
\end{array}$ \\
\hline $12 \mathrm{~L} 2$ & 0.073 & 0.073 & - & 0.088 & 156000 & 2650000 \\
\hline $18 \mathrm{~L} 2$ & 0.130 & 0.130 & - & 0.147 & 81000 & 550000 \\
\hline $24 \mathrm{~L} 2$ & 0.171 & 0.171 & - & 0.187 & 6300 & 57000 \\
\hline 54L2 & 0.270 & 0.246 & 0.024 & 0.307 & 510 & 4000 \\
\hline $100 \mathrm{~L} 2$ & 0.525 & 0.344 & 0.181 & 0.553 & 160 & 640 \\
\hline 192L2 & 0.825 & 0.379 & 0.446 & 1.316 & 80 & 180 \\
\hline $384 \mathrm{~L} 2$ & 1.500 & 0.467 & 1.033 & 2.459 & 20 & 20 \\
\hline $\begin{array}{l}\Delta_{\mathrm{p}} \varepsilon: \text { 主丕 } \\
\Delta \varepsilon_{\mathrm{t}}: \text { ホッ } \\
\mathrm{N}_{\mathrm{f}}: 95 \% \text { 耐 }\end{array}$ & 笁囲 & $\begin{array}{l}\varepsilon \mathrm{e}: \text { 弾性 } \\
\text { 务に対寸 } \\
\text { 労寿命) }\end{array}$ & の主歪 & $\begin{array}{r}\Delta \mathrm{p} \\
\mathrm{I}_{\mathrm{c}} \text { : 亀裂 }\end{array}$ & $\begin{array}{l}\text { : 塑性域 } \\
\text { 思回数 }\end{array}$ & 主歪範囲 \\
\hline
\end{tabular}

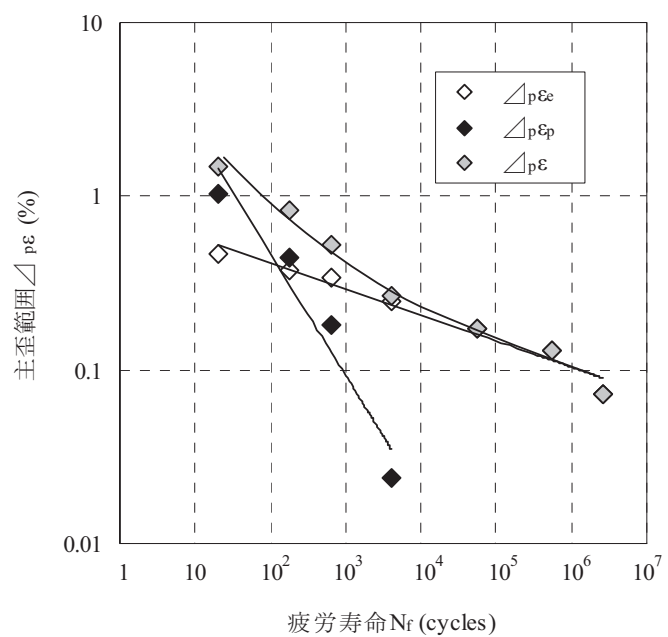

図 5 主歪範囲 - 疲労寿命の関係

ルで異なる特徴があることから、溶接止端部近傍の歪量の動向（弾 性歪と塑性歪の特徵）を考慮した評価方法を用いた方が的確である ことが判断される。そこで弾塑性域に渡って、を一N線図から主歪 範囲と疲労寿命 $\left(\Delta \mathrm{p} \varepsilon-\mathrm{N}_{\mathrm{f}}\right)$ の関係を直線で表すことができる Manson-Coffin則を用いた。

実験結果を表 2 に示す。同表より、降伏すると一方向ゲージのホ ットスポット応力に対する歪は大きくなるが、多軸応力状態である ことを考慮し 3 軸歪ゲージによる主歪を用いた。同表の主歪範囲と 疲労寿命 $\left(\triangle_{\mathrm{p}} \varepsilon-\mathrm{N}_{\mathrm{f}}\right)$ の関係を図 5 に示す。同図より、弾性域の 主歪範囲 $\left(\triangle_{\mathrm{p}} \varepsilon_{\mathrm{e}}\right)$ と塑性域の主歪範囲 $\left(\Delta_{\mathrm{p}} \varepsilon_{\mathrm{p}}\right)$ が、 $\Delta_{\mathrm{p}} \varepsilon$ と $\mathrm{N}_{\mathrm{f}}$ の 両対数軸上で直線関係を示したことから、Manson-Coffin則が成り立 つことが分かった。得られた回帰式を式(2) (4)に示す。

$$
\begin{aligned}
\triangle_{p} \varepsilon_{e} & =8.29 \times 10^{-3} N_{f}{ }^{-0.150} \\
\triangle_{p} \varepsilon_{p} & =1.18 \times 10^{-1} N_{f}^{-0.701} \\
\triangle_{p} \varepsilon & =\triangle_{p} \varepsilon_{e}+\triangle_{p} \varepsilon_{p} \\
& =8.29 \times 10^{-3} N_{f}^{-0.150}+1.18 \times 10^{-1} N_{f}^{-0.701}
\end{aligned}
$$

また、主歪方向と亀裂進展状沉を図 6 に示す。同図のように最大 引張主歪方向は 7 体全てが支管の軸歪方向となった。亀裂は、はじ めに溶接始終端部近傍に主歪方向と直角に初期亀裂が発生した。亀 裂は主管側の溶接止端部に沿って進展した後、止端部 I 付近でも新

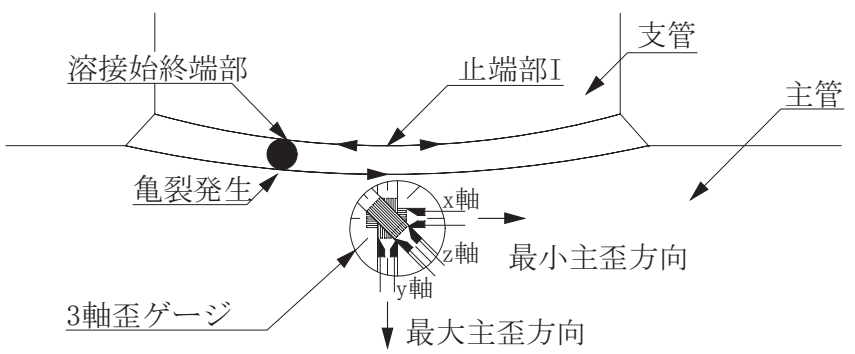

図 6 主歪方向と亀裂進展状況

表 32 段多重振幅疲労実験パラメータ及び結果

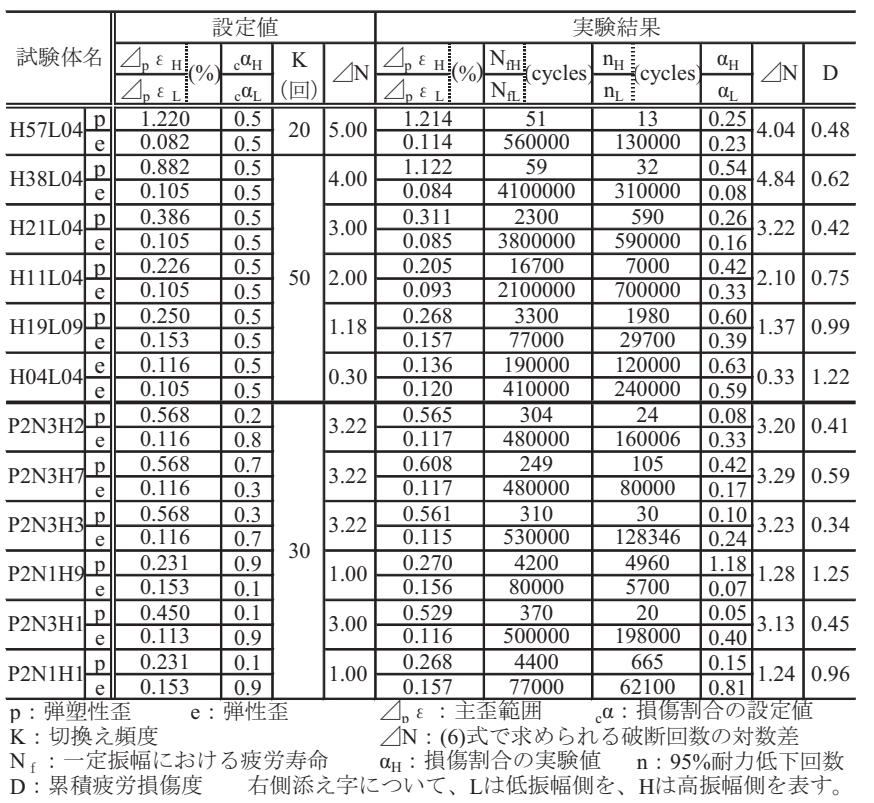

たな亀裂が発生し、支管側の溶接止端部に沿って左右に進展した。 亀裂の発生と進展に関しても 7 体全ての試験体がほぼ同じ結果とな った。また、以下に述べる多段多重振幅疲労実験における 25 体にお いても主歪方向及び亀裂の進展状況は全て同じ結果となった。

\section{4. 多段多重振幅疲労実験}

\section{1 線形累積疲労損傷則}

繰返し歪振幅がいくつかの歪振幅にわたって変動している場合の 疲労寿命の検討にはマイナー則を用いる。これは、ある一定の歪振 幅 $\Delta \varepsilon$ を $\mathrm{N}_{\mathrm{f}}$ 回繰返したとき破壊が起きるならば、その歪振幅を 1 回 受けると $1 / \mathrm{N}_{\mathrm{f}}$ だけの被害を受け、n回受けると $\mathrm{n} / \mathrm{N}_{\mathrm{f}}$ の被害を受けると いうことである。このような前提の下で、歪振幅が変動する多段多 重振幅においては、いくつかの $\Delta \varepsilon$ i 估存在し、それぞれの $\Delta \varepsilon$ iによ つて $\mathrm{n}_{\mathrm{i}} / \mathrm{N}_{\mathrm{fi}}$ の被害を受ける。このときの疲労被害 $\mathrm{n}_{\mathrm{i}} / \mathrm{N}_{\mathrm{fi}}$ の和が 1 になる と疲労破壊が生じるという考えで、その和を累積疲労損傷度 (D值) といい、式(5)を用いて算出した。

$$
D=\frac{n_{1}}{N_{f 1}}+\frac{n_{2}}{N_{f 2}}+\Lambda+\frac{n_{k}}{N_{f k}}=\sum_{i=1}^{k} \frac{n_{i}}{N_{f i}}
$$

$n_{i}$ : 多段多重振幅における、ある $1 つ の$ 振幅の総繰返し数 (cycles) $N_{f i}$ : 一定振幅における疲労寿命(cycles) 


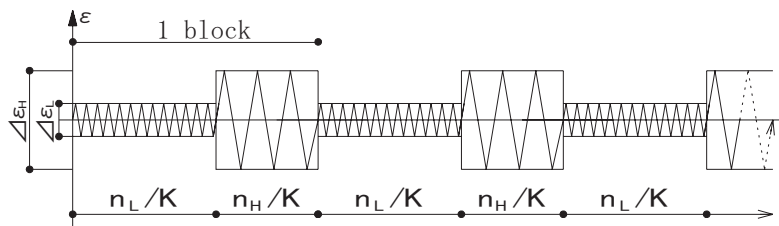

図 72 段多重振幅載荷パターン

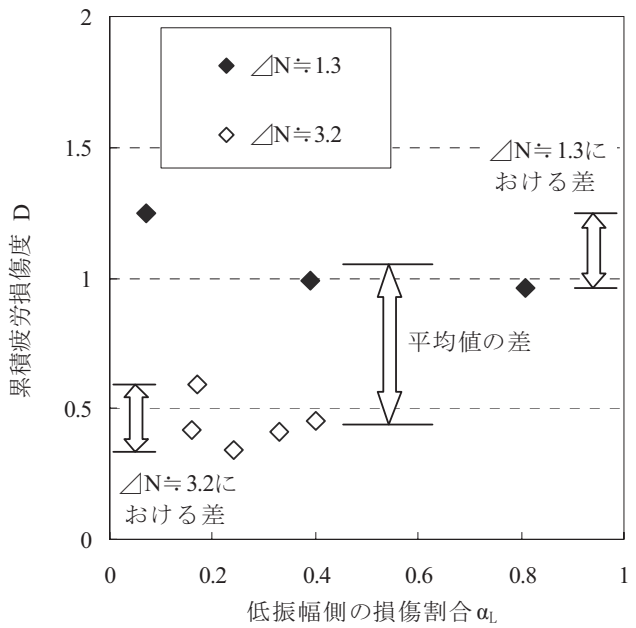

図 8 累積疲労損傷度 - 損傷割合の関係

\section{2 2 段多重振幅疲労実験}

2 段多重振幅疲労実験パラメータ及び結果を表 3 に示す。多段多 重振幅疲労実験においても一定振幅疲労実験と同様に主歪を用いた。 2 段多重振幅では、まず破断回数の対数差 $(\Delta \mathrm{N})$ の違いが累積疲労 損傷度（D 值）に及ぼす影響について検討するため、 $\Delta \mathrm{N}$ を $0.3 \sim 5.0$ に設定し 6 体について実験を行った。破断回数の対数差とは、高応 力により表面が凹凸になると、本来亀裂が発生しにくい低応力でも 早期に亀裂が発生し疲労寿命まで繰返し数が大幅に省かれるため、 低振幅側と高振幅側の繰返し数の対数をとり、その対数值の差を $\Delta$ $\mathrm{N}$ として式(6)に定義する。

$$
\Delta N=\log \left(N_{L}\right)-\log \left(N_{H}\right)
$$

$N_{L}$ : 低振幅側の一定振幅における疲労寿命（cycles）

$N_{H}$ : 高振幅側の一定振幅における疲労寿命 (cycles)

次に、2つの振幅が与える損傷割合 $\left({ }_{\mathrm{c}} \alpha\right)$ の違いが累積疲労損傷 度（D值）に及ぼす影響について検討寸るため、。 $\alpha_{\mathrm{L}}$ を $0.1 、 0.2 、 0.3 、$ 0.5、0.7、0.9 に設定し実験を行った。 $\alpha$ を式(7)に定義する。

$$
{ }_{c} \alpha_{L}+{ }_{c} \alpha_{H}=1
$$

${ }_{c} \alpha_{L}$ : 低振幅側の設定損傷割合 ${ }_{c} \alpha_{L}=\frac{n_{L}}{N_{L}}$

$$
{ }_{c} \alpha_{H} \text { : 高振幅側の設定損傷割合 }{ }_{c} \alpha_{H}=\frac{n_{H}}{N_{H}}
$$

$n_{L}:$ 低振幅側の総繰返し数 (cycles)

$N_{L}:$ 低振幅側の一定振幅における疲労寿命 (cycles)

$n_{H}:$ 高振幅側の総繰返し数 (cycles)

$N_{H}$ : 高振幅側の一定振幅における疲労寿命 (cycles)

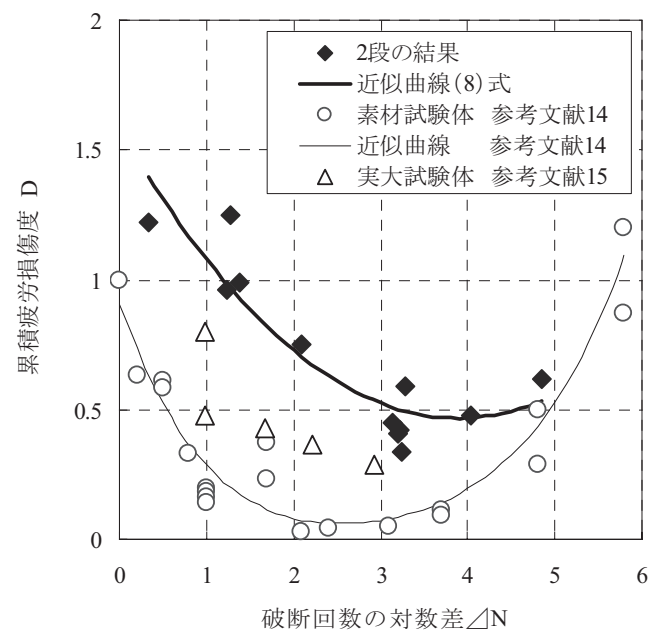

図 9 2 段の累積疲労損傷度 - 破断回数の対数差の関係

2 段多重振幅の載荷パターンを図 7 に示寸。載荷パターンは、同 図のように低振幅 $\left(\Delta \varepsilon_{\mathrm{L}}\right)$ から高振幅 $\left(\Delta \varepsilon_{\mathrm{H}}\right)$ 一、高振幅から低 振幅へと、耐力低下回数まで繰返した。また、各振幅を切換える回 数を切換え頻度 $(\mathrm{K})$ とし、同図のように低振幅と高振幅をセット で 1 ブロックとした。 1 体のみKを 20 回としたが実験結果より累積 疲労損傷度への影響はなかった。その他の試験体においては 30 回ま たは 50 回に設定した。ここで、同図の $\Delta \varepsilon_{\mathrm{L}}$ 及び $\Delta \varepsilon_{\mathrm{H}}$ は低振幅及び 高振幅を、 $\mathrm{n}_{\mathrm{L}}$ 及び $\mathrm{n}_{\mathrm{H}}$ は低振幅及び高振幅の総繰返し数を、 $\mathrm{n}_{\mathrm{L}} / \mathrm{K}$ 及び $\mathrm{n}_{\mathrm{H}} / \mathrm{K}$ は低振幅及び高振幅の 1 ブロックの繰返し数を表し、この $\mathrm{n}_{\mathrm{L}}$ 及 びn

実験結果より、まず $\triangle \mathrm{N}$ にってD值に大きく差があることから、 累積疲労損傷度に対して破断回数の対数差の影響が関係しているこ とが分かった。また、損傷割合の影響に関して、累積疲労損傷度 低振幅側の損傷割合（D值 - $\alpha_{\mathrm{L}}$ ）の関係を図 8 に示寸。同図は、 $\triangle$ Nがほぼ等しい試験体 $\triangle \mathrm{N} \fallingdotseq 1.3$ においてH19L09、P2N1H9、P2N1H1 の 3 体と、 $\triangle \mathrm{N} \fallingdotseq 3.2$ においてH21L04、P2N3H2、P2N3H7、P2N3H3、 $\mathrm{P} 2 \mathrm{~N} 3 \mathrm{H} 1$ の 5 体について検討した。D值には多少の差があるものの、 $\triangle \mathrm{N}$ による差の方が明らかに大きいことから、低振幅側の損傷割合 $\left(\alpha_{\mathrm{L}}\right)$ が累積疲労損傷度（D值）に与える影響は破断回数の対数差 $(\triangle \mathrm{N})$ に比べ少ないことが分かった。これより、12 体の試験体に おけるD值は $0.34 \sim 1.25$ の範囲となり、ほぼ 1 を下回ったことから、 マイナー則は疲労寿命を過大評価する傾向にあった。また、損傷割 合は $0.05 \sim 1.18$ の範囲となり、 $\triangle \mathrm{N}$ は 0.33〜4.84 の範囲となった。 これより実験結果から $\triangle \mathrm{N}$ はぼ設定值で実験が行えたことが分か った。

2 段多重振幅における累積疲労損傷度と破断回数の対数差 (D值 $\triangle \mathrm{N} ）$ の関係をSM490 鋼素材試験体の実験結果 ${ }^{15}$ 及び柱梁溶接接合 部を含む実大試験体の実験結果 ${ }^{16)}$ と併せて図 9 に示す。同図より、 本実験における結果は素材試験体及び実大試験体と同じような傾向 を示した。また、D值と $\Delta \mathrm{N}$ の間には関係があり、2 次曲線によって 近似することができた。その近似曲線を式(8)に示す。

$$
D=0.0737 \Delta N^{2}-0.572 \Delta N+1.58
$$

ここで、D 值が 1 よりも小さくなった要因としては、高応力によ 
表 43 段多重振幅疲労実験パラメータ及び結果

\begin{tabular}{|c|c|c|c|c|c|c|c|c|c|c|c|}
\hline \multirow{2}{*}{\multicolumn{2}{|c|}{ 試験体名 }} & \multicolumn{4}{|c|}{ 設定值 } & \multicolumn{6}{|c|}{ 実験結果 } \\
\hline & & \multirow{2}{*}{\begin{tabular}{||c|}
$\begin{array}{c}\triangle_{\mathrm{p}} \varepsilon \\
(\%)\end{array}$ \\
0.882
\end{tabular}} & ${ }_{c}^{\alpha}$ & \begin{tabular}{c|}
$\mathrm{K}$ \\
(回)
\end{tabular} & $\Delta \mathrm{N}_{\mathrm{ep}}$ & \multirow{2}{*}{\begin{tabular}{|c|}
$\begin{array}{r}\Delta_{\mathrm{p}} \varepsilon \\
(\%)\end{array}$ \\
1.031 \\
\end{tabular}} & \multirow{2}{*}{\begin{tabular}{|c|}
$\begin{array}{c}\mathrm{N}_{\mathrm{f}} \\
\text { (cycles) }\end{array}$ \\
71 \\
\end{tabular}} & \multirow{2}{*}{$\begin{array}{c}\begin{array}{c}n \\
\text { (cycles) }\end{array} \\
16\end{array}$} & \begin{tabular}{|c|}
$\alpha$ \\
023
\end{tabular} & $\triangle \mathrm{N}_{\mathrm{ep}}$ & D \\
\hline \multirow{3}{*}{ N4M032 } & $\mathrm{pp}$ & & 0.33 & & \multirow{3}{*}{3.35} & & & & 0.23 & \multirow{3}{*}{3.33} & \multirow{3}{*}{0.47} \\
\hline & - & \begin{tabular}{|l|}
0.321 \\
\end{tabular} & 0.33 & & & 0.305 & 2480 & 292 & 0.12 & & \\
\hline & $\mathrm{e}$ & 0.105 & 0.33 & & & 0.101 & 1250000 & 144839 & 0.12 & & \\
\hline \multirow{3}{*}{ N3M022 } & $\mathrm{p}$ & 0.386 & 0.33 & & \multirow{3}{*}{2.50} & 0.361 & 1270 & 168 & 0.13 & \multirow{3}{*}{2.50} & \multirow{3}{*}{0.53} \\
\hline & $\mathrm{p}$ & 0.226 & 0.33 & & & 0.241 & 7200 & 1665 & 0.23 & & \\
\hline & $\mathrm{e}$ & 0.105 & 0.33 & & & 0.105 & 1000000 & 167105 & 0.17 & & \\
\hline \multirow{3}{*}{ N2M019 } & $\mathrm{p}$ & \begin{tabular}{|l|}
0.260 \\
\end{tabular} & 0.33 & & \multirow{3}{*}{1.65} & 0.280 & 3600 & 1060 & 0.29 & \multirow{3}{*}{1.65} & \multirow{3}{*}{0.79} \\
\hline & $p$ & 0.190 & 0.33 & & & 0.196 & 21500 & 5278 & 0.25 & & \\
\hline & $\mathrm{e}$ & 0.116 & 0.33 & & & \begin{tabular}{|l|}
0.119 \\
\end{tabular} & 430000 & 105763 & 0.25 & & \\
\hline \multirow{3}{*}{ N1M019 } & p & 0.222 & 0.33 & & \multirow{3}{*}{0.82} & 0.239 & 7500 & 3419 & 0.46 & & \\
\hline & | & \begin{tabular}{|l|}
0.190 \\
\end{tabular} & 0.33 & & & \begin{tabular}{|l|}
0.197 \\
\end{tabular} & 21000 & 7771 & 0.37 & 0.82 & 1.19 \\
\hline & $\mathrm{e}$ & \begin{tabular}{|l|}
0.148 \\
\end{tabular} & 0.33 & 30 & & 0.152 & 94000 & 34290 & 0.36 & & \\
\hline & $\mathrm{p}$ & 0.882 & 0.33 & 30 & & 1.040 & 70 & 12 & 0.17 & & \\
\hline N4M012 & $\mathrm{e}$ & \begin{tabular}{|l|}
0.126 \\
\end{tabular} & 0.33 & & 3.74 & \begin{tabular}{|l|}
0.126 \\
\end{tabular} & 300000 & 29970 & 0.10 & 3.66 & 0.37 \\
\hline & $\mathrm{e}$ & 0.105 & 0.33 & & & \begin{tabular}{|l|}
0.104 \\
\end{tabular} & \begin{tabular}{|l|}
1050000 \\
\end{tabular} & 100207 & 0.10 & & \\
\hline & $\mathrm{pp}$ & 0.386 & 0.33 & & & 0.392 & 950 & 157 & 0.17 & & \\
\hline N3M012 & | & \begin{tabular}{|l|}
0.121 \\
\end{tabular} & 0.33 & & 2.80 & \begin{tabular}{|l|}
0.122 \\
\end{tabular} & 370000 & 62160 & 0.17 & 2.80 & 0.50 \\
\hline & $\mathrm{e}$ & 0.105 & 0.33 & & & 0.105 & 1000000 & 155872 & 0.16 & & \\
\hline & $\mathrm{p}$ & \begin{tabular}{|l|}
0.260 \\
\end{tabular} & 0.33 & & & 0.283 & 3400 & 895 & 0.26 & & \\
\hline $\mathrm{N} 2 \mathrm{M} 012$ & $\mathrm{e}$ & 0.126 & 0.33 & & 1.89 & 0.130 & 250000 & 53280 & 0.21 & 1.89 & 0.71 \\
\hline & $\mathrm{e}$ & \begin{tabular}{|l|}
0.116 \\
\end{tabular} & 0.33 & & & 0.122 & 370000 & 89062 & 0.24 & & \\
\hline & $\mathrm{p}$ & \begin{tabular}{|l|}
0.222 \\
\end{tabular} & 0.33 & & & 0.240 & 7400 & 2687 & 0.36 & & \\
\hline M015 & $\mathrm{e}$ & \begin{tabular}{|l|}
0.156 \\
\end{tabular} & 0.33 & & 0.93 & \begin{tabular}{|l|}
0.157 \\
\end{tabular} & 77000 & 19536 & 0.25 & 0.94 & 0.89 \\
\hline & $\mathrm{e}$ & \begin{tabular}{|l|}
0.148 \\
\end{tabular} & 0.33 & & & \begin{tabular}{|l|}
0.150 \\
\end{tabular} & 100000 & 28165 & 0.28 & & \\
\hline & $\mathrm{p}$ & 0.386 & 0.20 & & & 0.400 & 890 & 90 & \begin{tabular}{|l|}
0.10 \\
\end{tabular} & & \\
\hline N3M116 & e & \begin{tabular}{|l|}
0.116 \\
\end{tabular} & 0.40 & & 3.00 & 0.116 & 500000 & 90000 & 0.18 & 3.32 & 0.50 \\
\hline & $\mathrm{e}$ & 0.094 & 0.40 & 20 & & 0.096 & 1800000 & 400000 & 0.22 & & \\
\hline & $p$ & 0.386 & 0.20 & & & \begin{tabular}{|l|}
0.421 \\
\end{tabular} & 750 & 120 & 0.16 & & \\
\hline N3M16 & $\mathrm{e}$ & \begin{tabular}{|l|}
0.169 \\
\end{tabular} & 0.40 & & 2.50 & \begin{tabular}{|l|}
0.167 \\
\end{tabular} & 54000 & 12000 & 0.22 & 2.80 & 0.65 \\
\hline & \begin{tabular}{|c|c|}
$\mathrm{e}$ & \\
\end{tabular} & \begin{tabular}{|l|}
0.094 \\
\end{tabular} & 0.40 & & & 0.096 & \begin{tabular}{|l|}
1800000 \\
\end{tabular} & 480000 & 0.27 & & \\
\hline $\begin{array}{l}\mathrm{N}_{\mathrm{f}}: \text { 一只 } \\
\alpha: \text { 損傷 }\end{array}$ & 蛪 & 㫳幅に & . & & & & $\begin{array}{l}\mathrm{n}: 95 \% \\
\mathrm{D}: \text { 累栍 }\end{array}$ & 低下 & 崱賃害 & & 它值 \\
\hline
\end{tabular}

り表面が凹凸になることで亀裂が発生しやすい状態となり、本来亀 裂が発生しにくい低応力でも早期に亀裂が発生したものと考えられ る。通常、弾性範囲の疲労では亀裂発生までに多数の繰返しを要す るが、塑性域での繰返しにより表面が凹凸になると、弾性域の繰返 しでも非常に早く亀裂が発生し20)、多くの繰返しが省かれるのでD 值が低下寸る。

\subsection{3 段多重振幅疲労実験}

3 段以上の多段多重振幅では、損傷割合を考慮して弾性歪と弾塑 性歪における等価振幅（ $\left.\Delta \mathrm{N}_{\mathrm{e}} 、 \Delta \mathrm{N}_{\mathrm{p}}\right)$ から、3 段以上の破断回数の 対数差（ $\left.\triangle \mathrm{N}_{\mathrm{ep}}\right)$ を式(9) (11)のように定義し、算出した。

$$
\begin{aligned}
& \Delta N_{e p}=\Delta N_{e}-\Delta N_{p} \\
& \Delta N_{e}=\sum_{i=1}^{k} \frac{1}{k} \log \left(\alpha_{e i} \times N_{f e i}\right) \\
& \Delta N_{p}=\sum_{i=1}^{k} \frac{1}{k} \log \left(\alpha_{p i} \times N_{f p i}\right)
\end{aligned}
$$

$\Delta N_{e}$ : 弾性歪における疲労寿命の対数值の平均 $\triangle N_{p}$ : 弾塑性歪における疲労寿命の対数值の平均 $\alpha_{e i}$ : 弾性歪の損傷割合 $\quad \alpha_{p i}$ : 弾塑性歪の損傷割合

$N_{f e i}$ : 弾性歪の一定振幅における疲労寿命 (cycles)

$N_{f p i}$ : 弾塑性歪の一定振幅における疲労寿命（cycles）

3 段多重振幅疲労実験パラメータ及び結果を表 4 に示す。パラメ 一タに関しては、10 体の試験体において弾性範囲と弾塑性範囲の歪 振幅を組み合わせたものとし、Kは 20 回と 30 回に設定した。また、 c $\alpha$ は、2 段多重振幅において $0.1 \sim 0.9$ の範囲で実験を行い、D值に

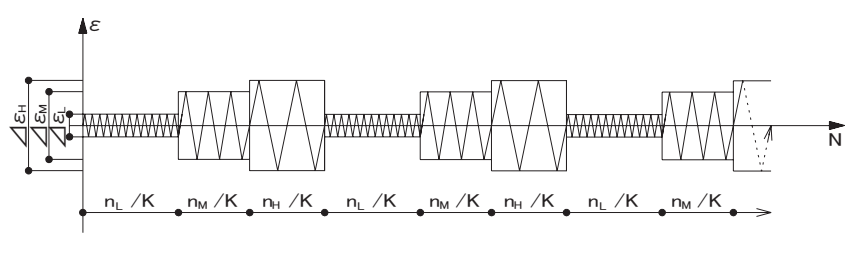

図 103 段多重振幅載荷パターン

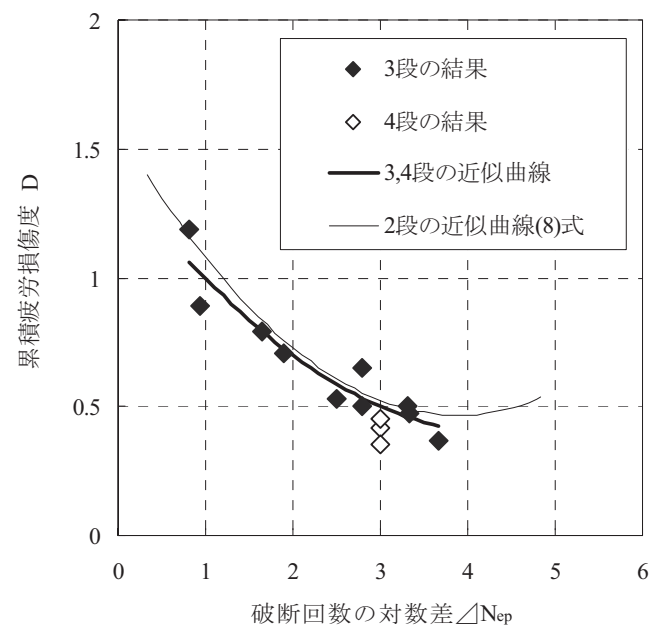

図 113 段及び 4 段の累積疲労損傷度 - 歪振幅差の関係
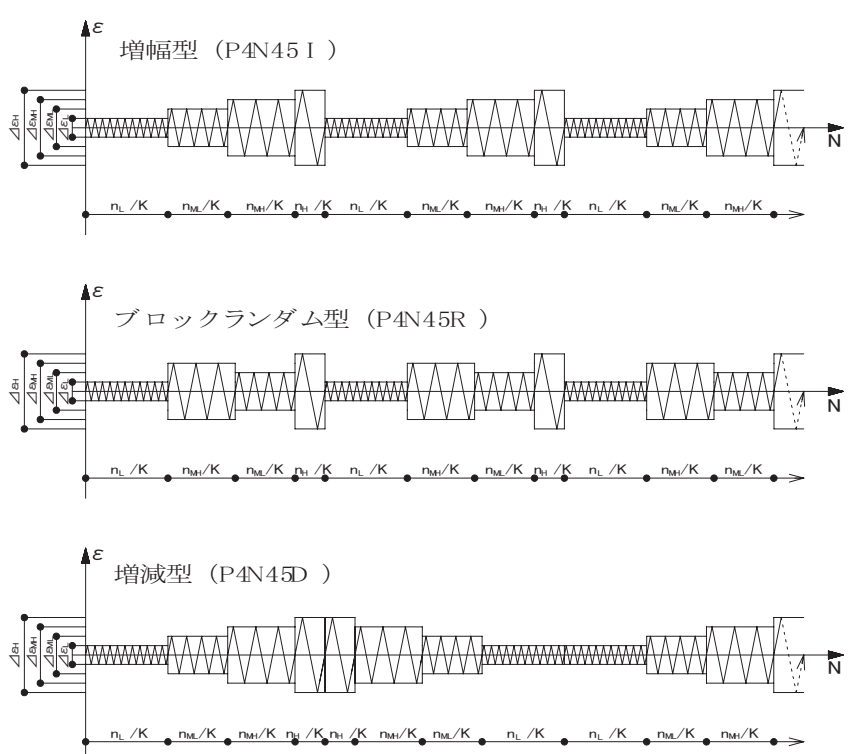

図 124 段多重振幅載荷パターン

及ぼす影響がそれほどないことから、3 段多重振幅では 3 つの振幅 がそれぞれ均等となるように 0.33 ずつとしたものを 8 体、他の 2 体は。 $\alpha$ を $0.2 \sim 0.4$ の範囲で変化させたものとした。 3 段多重振幅の 載荷パターンを図 10 に示す。載荷パターンは、低振幅から中振幅側、 高振幅側と切換える増幅型とした。

実験結果を、2 段多重振幅疲労実験の実験結果から得た近似曲線 (8)式と合わせて図 11 に示寸。同図より、3 段多重振幅の累積疲労損 傷度と破断回数の対数差 (D值 $-\Delta \mathrm{N}_{\mathrm{ep}}$ ) の関係は、2 段多重振幅の $\mathrm{D}$ 值 - $\Delta \mathrm{N}$ 関係と近い值を示していることが分かった。 
表 54 段多重振幅疲労実験パラメータ及び結果

\begin{tabular}{|c|c|c|c|c|c|c|c|c|c|c|c|}
\hline \multirow{2}{*}{\multicolumn{2}{|c|}{ 試験体名 }} & \multicolumn{4}{|c|}{ 設定值 } & \multicolumn{6}{|c|}{ 実験結果 } \\
\hline & & $\begin{array}{l}\triangle_{\mathrm{p}} \varepsilon \\
(\%)\end{array}$ & $c^{\alpha}$ & $\begin{array}{c}\mathrm{K} \\
\text { (回) }\end{array}$ & $\Delta \mathrm{N}_{\mathrm{ep}}$ & $\begin{array}{l}\triangle_{\mathrm{p}} \varepsilon \\
(\%)\end{array}$ & $\begin{array}{c}\mathrm{N}_{\mathrm{f}} \\
\text { (cycles) }\end{array}$ & $\begin{array}{c}\mathrm{n} \\
\text { (cycles) }\end{array}$ & $\alpha$ & $\Delta \mathrm{N}_{\mathrm{e}}$ & D \\
\hline \multirow{4}{*}{ P4N45I } & $p$ & 0.975 & 0.25 & \multirow{12}{*}{20} & \multirow{4}{*}{3.00} & 1.152 & 56 & 7 & 0.13 & \multirow{4}{*}{3.00} & \multirow{4}{*}{0.42} \\
\hline & $\mathrm{p}$ & 0.304 & 0.25 & & & 0.317 & 2110 & 217 & 0.10 & & \\
\hline & $\mathrm{e}$ & 0.156 & 0.25 & & & 0.155 & 82000 & 7000 & 0.09 & & \\
\hline & $\mathrm{e}$ & 0.091 & 0.25 & & & 0.092 & 2300000 & 221357 & 0.10 & & \\
\hline \multirow{4}{*}{ P4N45R } & $\mathrm{p}$ & 0.975 & 0.25 & & \multirow{4}{*}{3.00} & 1.076 & 65 & 7 & 0.11 & \multirow{4}{*}{3.00} & \multirow{4}{*}{0.35} \\
\hline & $\mathrm{p}$ & 0.304 & 0.25 & & & 0.310 & 2330 & 217 & 0.09 & & \\
\hline & 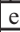 & \begin{tabular}{|l|l|}
0.156 \\
\end{tabular} & 0.25 & & & 0.152 & 94000 & 7000 & 0.07 & & \\
\hline & $\mathrm{e}$ & 0.091 & 0.25 & & & 0.089 & 2650000 & 221457 & 0.08 & & \\
\hline \multirow{4}{*}{ P4N45D } & $\mathrm{p}$ & 0.975 & 0.25 & & \multirow{4}{*}{3.00} & 0.846 & 110 & 10 & 0.09 & \multirow{4}{*}{3.00} & \multirow{4}{*}{0.45} \\
\hline & $\mathrm{p}$ & 0.304 & 0.25 & & & 0.314 & 2200 & 313 & 0.14 & & \\
\hline & $\mathrm{e}$ & 0.156 & 0.25 & & & 0.151 & 97000 & 10000 & 0.10 & & \\
\hline & 5 & 0.091 & 0.25 & & & 0.090 & 2650000 & 316226 & 0.12 & & \\
\hline
\end{tabular}
$\mathrm{K}$ : 切換え頻度 $\triangle \mathrm{N}_{\mathrm{ep}}$ : (9)式で求められる破断回数の対数差 $\mathrm{N}_{\mathrm{f}}$ : 一定振幅における疲労寿命 $\mathrm{n}$ : $95 \%$ 耐力低下回数 $\alpha$ : 損傷割合実験值 $\quad \mathrm{D}$ : 累積疲労損傷度

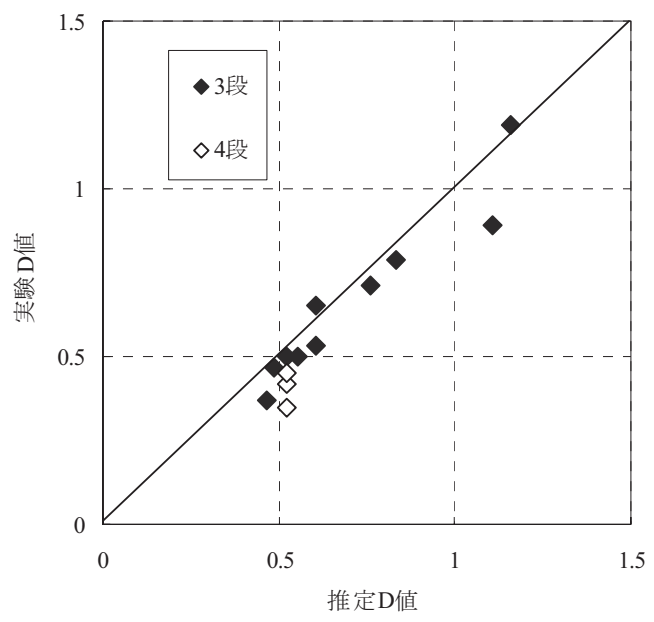

図 133 段及び 4 段の実験 D 值 - 推定 D 值の関係

\subsection{4 段多重振幅疲労実験}

4 段多重振幅の載荷パターンでは、増幅型のみでは異なる振幅に おいて隣り合わない振幅が出てくること、また隣り合う振幅の影響 について検討するために、増幅型の他に、増減型、ブロックランダ ム型の 3 パターンで実験を行った。4 段多重振幅の載荷パターンを 図 12 に示寸。

4 段多重振幅疲労実験パラメータ及び結果を表 5 に示す。3 体の試 験体は、載荷パターンのみを変化させ、その他のパラメータは同じ とした。 $\alpha$ は 4 つの振幅が均等となるように 0.25 ずつとし、Kは 20 回に設定した。同表の実験結果より、D值が近い值を示しているこ とから、載荷パターンの違いによる累積疲労損傷度への影響が少な いことが分かる。また、累積疲労損傷度と破断回数の対数差（D值 - $\triangle \mathrm{N}_{\mathrm{ep}}$ ) の関係を図 11 に示す。 D值が $0.35 \sim 0.45$ となり、 4 段多重 振幅の結果も 2 段多重振幅の結果とほぼ同じとなった。

\section{5 多段多重振幅の疲労寿命の推定}

多段多重振幅における疲労寿命には、累積疲労損傷度（D値）と 破断回数の対数差 $\left(\triangle \mathrm{N} 、 \Delta \mathrm{N}_{\mathrm{ep}}\right)$ の間に関係があり、マイナー則の 適用が過大評価になることを示し、また傾向が伺えた。図 11 では、 3 段及び 4 段多重振幅の近似曲線が 2 段多重振幅の近似曲線とほぼ 同じとなったことから、3 段以上の多段多重振幅では 2 段多重振幅 の $\triangle \mathrm{N}$ に相当するものとして、弾性歪と弾塑性歪の等価振幅の差を
とった $\Delta \mathrm{N}_{\mathrm{ep}}$ を用いてD值 - $\Delta \mathrm{N}_{\mathrm{ep}}$ 関係を示すことができた。ここで、 3 段及び 4 段多重振幅の累積疲労損傷度の実験值と 2 段多重振幅の 近似曲線 (8)式における推定值（実験D值 - 推定D值）の関係を、図 13 に示す。同図より、3 段及び 4 段多重振幅の累積疲労損傷度は 2 段多重振幅の近似曲線(8)式によって精度よく推定できることが分 かった。

これより、3 段及び 4 段の多段多重振幅における疲労寿命を推定 するには、 $\varepsilon-\mathrm{N}$ 線図を求めるための一定振幅載荷実験とそれに基 づいた 2 段多重振幅疲労実験を行い、累積疲労損傷度と破断回数の 対数差（D 值 - $\Delta \mathrm{N}$ ）の関係を示すことにより推定可能といえる。

\section{5. まとめ}

$\mathrm{T}$ 字型鋼管分岐溶接継手を用いた各種疲労実験により、以下の知 見を得た。

(1) 2 段多重振幅において、累積疲労損傷度（D 值）は一定となら ず、破断回数の対数差 $(\triangle \mathrm{N})$ との関係を 2 次曲線で近似する ことができ、 $\triangle \mathrm{N}$ が 3.23 のとき $\mathrm{D}$ 值が最小で 0.34 となった。

(2) 3 段及び 4 段の多段多重振幅の疲労寿命を評価する際には、2 段多重振幅における $\Delta \mathrm{N}$ に相当する等価振幅から求めた $\Delta \mathrm{N}_{\mathrm{ep}}$ を用いることで、2 段多重振幅の $\mathrm{D}$ 值 - $\Delta \mathrm{N}$ 曲線で推定が可能 であった。

（3）切換え頻度（K）が十分に大きければ、載荷パターン及び損傷 割合（ $\alpha$ ) の違いは、累積疲労損傷度（D值）に対してほとん ど影響がない。

今後の課題として、ダンパー用鋼材や柱梁の溶接部を含む実大試 験体に関して S - N 線図に基づき多段多重振幅疲労実験で D 值 - $\Delta$ $\mathrm{N}$ 関係について引き続き検討していく必要がある。また、残留応力 の影響やD值が低下寸る要因及びメカニズムに関してミクロ的な検 討を加えることも必要である。

\section{参考文献}

1) 成原弘之, 泉満, 浅見豊 : 風荷重に対寸る高層鋼構造骨組の疲労設計, 日本 建築学会構造系論文集，第 465 号, pp.129-137, 1994.11

2) 中込忠男, 李建, 佐々木康彰, 原山浩一, 岩本剛: SN490B 鋼を用いた梁 端溶接接合部の疲労特性に関寸る研究, 鋼構造年次論文報告集, 第 5 巻, pp.71-76, 1997.11

3) 小川秀雄, 大熊武司, 中込忠男 : 大型試験体を用いた両振り一定振幅載荷 の疲労強度一鋼構造柱梁溶接接合部の累積疲労損傷評価 その 1 一, 日本 建築学会構造系論文集, 第 535 号, pp.149-156, 2000.9

4) 中込忠男, 岩本剛, 加村久哉, 下川弘海, 原山浩一, 低降伏点鋼を用いた 鋼管補剛平鋼ブレースの疲労特性に関する実験的研究, 日本建築学会構造 系論文集，第 530 号，pp.155-161，2000.4

5) 小川秀雄, 大熊武司, 中込忠男, 上遠野明夫, 河合良道 : 柱梁溶接接合部 の降伏応力度近傍載荷での疲労実験, 鋼構造年次論文報告集, 第 2 巻, pp.367-374, 1994.11

6) 小川秀雄, 大熊武司, 中込忠男, 上遠野明夫, 下村祥一 : 柱梁溶接接合部 の降伏応力度近傍載荷での疲労実験 II, 鋼構造年次論文報告集, 第 4 巻, pp.121-128, 1996.11

7) 花井正実, 黒羽啓明, 吉村浩二, 藤田文雄 : 鋼素材の低サイクル疲労挙動 に関する実験的研究, 日本建築学会論文報告集, 第 184 号, pp.29-37, 1971.6 8) 藤本盛久, 青木博文, 中込忠男, 三木千寿: 繰返し塑性歪を受ける構造用 鋼材の力学的性能, 構造工学シンポジウム, 第 20 回, pp.15-22, 1976.1

9) 藤本盛久, 泉満 : 欠陥を有する溶接部の変形能力に関する研究, $\mathrm{T}$ 継手突 
合せ溶接部の低サイクル塑性疲労実験, その 1 , 日本建築学会論文報告集, 第 288 号, pp.61-72, 1980.2

10) 藤本盛久, 泉満 : 久陥を有する溶接部の変形能力に関する研究, $\mathrm{T}$ 継手突 合せ溶接部の低サイクル塑性疲労実験, その 2, 日本建築学会論文報告集, 第 303 号, pp.21-30, 1981.5

11) 金多潔, 甲津功夫 : 鋼構造溶接接合部の低サイクル疲労強度に関する実験 的研究一その 1 , 各種鋼材とその溶接接合部の疲労強度一, 日本建築学会 論文報告集，第 313 号，pp.30-38，1982.3

12) 金多潔, 甲津功夫 : 鋼構造溶接接合部の低サイクル疲労強度に関する実験 的研究一その 2, 理想化された柱はり溶接接合部の疲労強度一, 日本建築 学会論文報告集，第 317 号，pp.15-22，1982.7

13) Miner.M.A : Cumulative Damage in Fatigue, Jour of Applied Mech, Vol.12, pp.A159-164, 1945.9

14) 例えば，日本材料学会編，金属材料疲労設計便覧，養賢堂，1978.10 日本機械学会編，機械工学便覧， $\alpha$. 基礎編，丸善，2007.10

15) 中込忠男, 李建 : 繰返し力を受ける SM490 鋼の疲労性に関する研究, 日 本建築学会構造系論文集，第469 号, pp.127-136, 1995.3

16) 大熊武司, 中込忠男, 小川秀雄, 村井正敏, 他 : 鋼構造柱梁溶接接合部の 累積疲労損傷に関寸る研究 その 9 二段多重振幅載荷実験, 日本建築学 会大会学術講演梗概集，C-1，pp.439-440， 1998.9

17) 堀田知道, 村木潤次郎, 石黒隆義, 石井伸幸, 関口進 : 鋼材の歪制御低サ イクル疲労強度推定に関する研究 (第 1 報), 日本造船学会論文集, 第 124 号, pp.341-353, 1968.12

18) 堀田知道, 石黒隆義, 石井伸幸, 関口進: 鋼材の歪制御低サイクル疲労強 度推定に関する研究 (第 2 報), 日本造船学会論文集, 第 126 号, pp.357-365, 1969.12

19) 堀田知道, 石黒隆義, 石井伸幸, 宮健三, 関口進 : 鋼材の歪制御低サイク ル疲労強度推定に関する研究（第 3 報）, 日本造船学会論文集, 第 128 号, pp.317-330, 1970.12

20) L.Persoz, R.Cazaud, G.Pomey 著, 舟久保熙康, 西島敏 訳, 金属の疲れ, 丸善, 1973.5

21) 安藤彰教, 中込忠男: 鋼管分岐溶接継手の多段多重振幅における疲労特性 に関する実験的研究, 日本建築学会大会学術講演梗概集, C-1, pp.743-744, 2007.8
22) 成原弘之, 泉満 : 鋼構造柱梁仕口における梁端溶接部の疲労強度, 日本建 築学会構造系論文集, 第 508 号, pp.111-117, 1998.6

23）日本鋼構造協会編: 鋼構造物の疲労設計指針・同解説，技報堂出版，1993.4 24) 玉井宏章, 近藤一夫, 花井正実 : 履歷減衰装置の極低サイクル疲労特性と 実地震応答下における疲労寿命の予測, 日本建築学会構造系論文集, 第 462 号, pp.141-150, 1994.8

25) 飯田国広 : HT60 鋼の歪制御低サイクル疲労における亀裂発生寿命と破面 のミクロフラクトグラフィ, 日本造船学会論文集, 第 128 号, pp.331-342, 1970.12

26) 飯田国広, 井上肇: 低サイクル疲労寿命の分布形状に基づいた疲労設計曲 線の一考察, 日本造船学会論文集, 第 133 号, pp.235-249, 1973.6

27) 飯田国広, 高允宝 : ヒステリシスエネルギーに基づいた疲労強度減少係数 の一考察, 日本造船学会論文集, 第 134 号, pp.341-350, 1973.12

28) 菊川真, 城野政弘, 宋智浩 : 実働荷重下の繰返し塑性ひずみと累積疲労損 傷（疲労限度以下の領域における限界修正 S-N 曲線）, 材料, 第 252 号, pp.743-750, 1974.9

29) 菊川真, 城野政弘, 宋智浩 : 繰返し塑性ひずみと累積疲労損傷值（疲労限 度以下の応力による疲労損傷), 材料, 第 227 号, pp.753-758, 1972.8

30) 幡中憲治: 金属材料の繰返し応力ーひず夕特性と低サイクル疲労寿命, 日 本機械学会論文集，第453 号, pp.831-838，1984.5

31) 幡中憲治, 藤満達郎, 渡辺秀明 : 金属材料の疲労限度近傍における繰返し 変形特性とひずみ一疲労寿命曲線, 日本機械学会論文集, 第 474 号, pp.267-274, 1986.2

32) 遠藤達雄 : 実疲労被害評価法の一断面（レインフロウ法の考え方を中心と して)，日本機械学会論文集，第 501 号，pp.869-874，1988.5

33) 菊川真, 城野政弘, 村田洋一: 繰返し塑性ひずみと累積損傷值に及ぼす平 均応力の影響，材料，第 325 号，pp.998-1004，1980.10

34）西村俊夫，三木千寿: 構造用鋼材のひずみ制御低サイクル疲れ特性，日本 土木学会論文集，第 279 号, pp.26-44, 1978.11

35) 城野政弘, 花井正博, 菊川真 : 疲労限以下の累積疲労損傷に及ぼす過大過 小応力頻度比の影響 (主として過小応力が引張平均応力の場合), 材料, 第 361 号, pp.1137-1143, 1983.10

(2008年 9 月10日原稿受理，2009年 1 月29日採用決定） 